\title{
MAFHUM MUWAFAQAH DAN IMPLIKASINYA DALAM ISTINBATH HUKUM
}

\author{
Evra Willya*
}

\begin{abstract}
Abstrak
Mafhum adalah setiap makna yang dipahami dari suatu lafaz yang makna tersebut berada di ruang lingkup yang tersurat. Persoalan mafhum termasuk dalam pembahasan ushul fikih ketika ulama ushul fikih membahas kaidah-kaidah bahasa dalam rangka memahami kandungan suatu nash. Ulama ushul fikih membagi mafhum kepada dua, yaitu mafhum muwafaqah dan mafhum mukhalafah. Ketika membicarakan mafhum muwafaqah -yang menurut Hanafiyah disebut dengan dilalah al-nash-seluruh ulama kecuali Zhahiriyah sepakat berhujjah dengan mafhum muwafaqah, akan tetapi mereka berbeda pendapat mengenai cara menetapkan hukum melalui mafhum muwafaqah ini. Pendapat pertama menyatakan bahwa penunjukkkan lafaz terhadap mafhum muwafaqah dilakukan melalui cara qiyas, sedangkan pendapat kedua menyatakan bahwa pemahaman terhadap makna-makna tersebut dilakukan melalui dilalah lafaz. Perbedaan mereka ini berpengaruh terhadap hukum yang dihasilkan dalam memahami suatu nash.
\end{abstract}

Kata kunci: Mafhum muwafaqah, dilalah lafaz, qiyas

\section{A. Pendahuluan}

Hukum Islam menghadapi tantangan lebih serius, terutama pada abad kemajuan ilmu pengetahuan dan teknologi. Untuk menjawab berbagai permasalahan baru yang berhubungan dengan hukum Islam, para ahli sudah tidak bisa lagi mengandalkan ilmu tentang fikih, hasil ijtihad ulama di masa lampau. Alasannya karena ternyata warisan fikih yang terdapat dalam buku-buku klasik, bukan saja terbatas

* Evra Willya adalah tenaga pengajar pada STAIN Bukittinggi. 
kemampuannya dalam menjangkau masalah-masalah baru yang belum ada sebelumnya, melainkan juga di sana sini mungkin terdapat pendapat yang tidak atau kurang relevan dengan abad kemajuan ini. Oleh karena itu umat Islam perlu mengadakan penyegaran kembali terhadap warisan fikih, dan yang paling penting lagi agar mampu me- nemukan rumusan-rumusan baru fikih dalam rangka memberikan jawaban terhadap masalah-masalah sekarang yang belum ada jawaban- nya. Dalam konteks ini ijtihad menjadi sebuah kemestian. Dan metode ijtihad mutlak harus dikuasai oleh mereka yang akan melakukannya. Salah satu di antara metode istinbath hukum dalam berijtihad adalah mafhum muwafaqah.

\section{B. Petunjuk Lafaz terhadap Hukum}

\section{Petunjuk Lafaz terhadap Hukum versi Ulama Hanafi dan al-Mutakallimin}

Di kalangan ulama ushul fikih terdapat dua versi pembagian lafaz ditinjau dari cara yang digunakan untuk mengetahui petunjuk lafaz terhadap hukum sebagai pengertian yang dikehendaki oleh pembicara. Versi pertama adalah versi ulama Hanafi dan versi kedua adalah versi ulama Mutakallimin atau Jumhur ulama. Ulama Hanafi mem- bagi kepada empat yaitu 'ibarah, isyarah, dilalah dan iqthidha' al-nash, sedangkan ulama Mutakallimin membagi kepada dua yaitu manthuq dan mafhum.

\section{Ulama Hanafi}

Ulama Hanafi membagi petunjuk lafaz terhadap hukum kepada 4 macam, yaitu:

a. Ibarah al-nash

Al-Sarakhsi mendefinisikan ibarah al-nash dengan:

\footnotetext{
Nama lengkapnya adalah Abu Bakr bin Muhammad bin Ahmad bin Abi Sahl al-Sarakhsi. Ahli fikih, usul fikih, teologi dan hadis. Ia adalah salah seorang ulama terbesar Mazhab Hanafi, tetapi riwayat hidupnya tidak ditemukan secara lengkap, lahir di Sarakhs (Sarkhas) sebuah kota besar yang terletak di Khurasan. Tahun kelahirannya tidak ditemukan, sedangkan mengenai tahun
} 
ما كان السياق لأجله و يعلم قبل التأمل أن ظاهر النص متناول له "Penunjukan terhadap suatu makna berdasarkan susunan kalimatnya dan makna atau pengertian itu dapat diketahui tanpa melalui penelitian. Mencakup di dalamnya zhahir nash.

Amir Bad Syah mendefinisikan ibarah al-nash dengan:

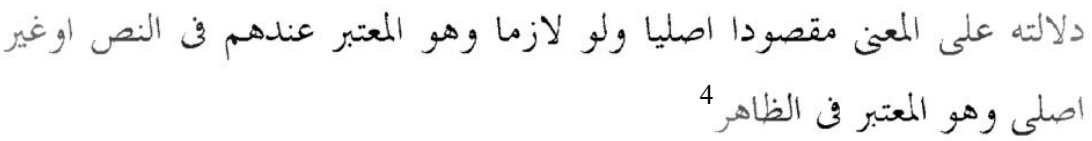

"Penunjukan lafaz atas makna sesuai dengan maksud asli, meskipun dalam bentuk lazim (makna ini dipandang sebagai makna nash) atau sesuai dengan maksud yang tidak asli (makna ini dipandang sebagai makna zhahir."

Kedua definisi ini mengandung arti bahwa hukum yang dimaksud dapat langsung dipahami dari lafaz yang disebutkan. Pengertian yang ditunjukkan oleh lafaz secara langsung dari susunan kalimat dan makna tersebut merupakan maksud dari lafaz itu. Makna yang dimaksud itu adakalanya makna asli (nash) dan adakalanya merupakan makna yang tidak asli (zhahir).

Misal, surat al-Baqarah ayat 275 yang menyatakan bahwa Allah telah menghalalkan jual beli dan mengharamkan riba. Ayat ini menurut ibarahnya menunjukkan dua makna, pertama pembedaan

wafatnya terdapat perbedaan pendapat ada yang mengatakan $483 \mathrm{H}$, dan ada yang mengatakan tahun $490 \mathrm{H}$. Abu al-Wafa' al-Afghani, dalam kata pengantar pada kitab Ushul al-Sarakhsi, (Bairut: Dar al-Kutub al-Ilmiyyah, 1993), Juz I, h. 4-7.

Abu Bakr Muhammad bin Ahmad bin Abi Sahl al-Sarakhsi, Ushul alSarakhsi, ditahqiq oleh Abu al-Wafa' al-Afghani, (Bairut: Dar al-Kutub alIlmiyyah, 1993), Juz I, h. 236.

Nama lengkapnya adalah Muhammad Amin, di kenal dengan Amir Bad Syah alBukhara bermazhab Hanafi. Tidak ditemukan tahun lahir dan tahun wafatnya.

Beliau mengarang kitab Taisir al-Tahrir. Kitab ini merupakan syarah dari kitab Tahrir fu ushul al-Figh, yang dikarang oleh Kamal al-Din Muhammad bin abd alWahid yang popular dengan nama Ibn Humam al-Hanafi. Mushthafa bin Abd Allah al-Qushthanthani al-Rumi al-Hanafi. Kasyf al-Zhunun 'an Asami al-Kutub wa al-Funun, (Bairut: Dar al-Fikr, 1994), jilid 1, h. 308.

Amir Bad Syah, Taisir al-Tahrir Syarh 'Ala Kitab al-Tahrir fi Ushul al-Fiqh, (Bairut: Dar al-Kutub al-Ilmiyyah. 1993), Juz 1, h. 86. 
antara jual beli dan riba (jual beli tidak sama dengan riba), dan kedua, pembolehan jual beli dan pengharaman riba. Kedua makna ini adalah pengertian yang dipahami dari ungkapan nash dan keduanya dimaksudkan oleh susunan katanya. Tetapi makna yang pertama adalah tujuan semula ayat diturunkan, yaitu untuk menangkis dan membantah pernyataan orang-orang yang mengatakan bahwa jual beli itu sama dengan riba. Sedangkan yang kedua adalah makna yang mengikut karena meniadakan persamaan itu adalah menjelaskan hukum masing-masing dari jual beli dan riba.

Kekuatan Ibarah al-nash bertingkat-tingkat sesuai dengan kejelasan arti lafaznya. Penunjukan ibarat dalam bentuk nash lebih kuat dibandingkan ibarat dalam bentuk zhahir. Alasannya karena penunjukan lafaz nash terhadap apa yang dimaksud adalah secara langsung dan berdasarkan maksud asalnya, sedangkan penunjukan lafaz secara zhahir meski jelas tetapi tidak langsung dan tidak untuk maksud yang sebenarnya dari lafaz tersebut.

b. Isyarah al-nash

Al-Sarakhsi mendefinisikan isyarah al-nash dengan

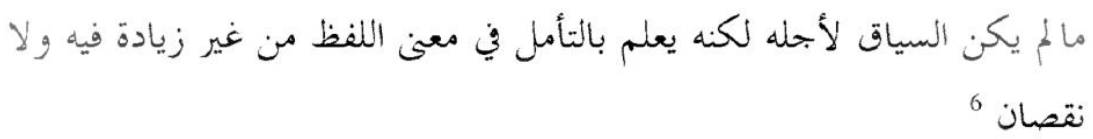

"Apa yang terungkap memang bukan ditujukan untuk itu, namun dari penelitian yang mendalam ditemukan suatu makna dari lafaz itu tidak lebih dan tidak kurang."

Amir Bad Syah mendefinisikan isyarah al-nash dengan

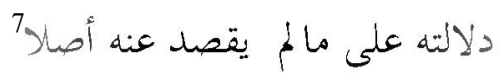

"Lafaz yang penunjukannya terhadap sesuatu tidak dimaksudkan untuk itu menurut asalnya."

Amir Syarifuddin, Ushul Fiqh, (Jakarta: Logos, 1999), Jilid 2, h. 131. Abu Bakr Muhammad bin Ahmad bin Abi Sahl al-Sarakhsi, Ushul alSarakhsi, ditahqiq oleh Abu al-Wafa' al-Afghani, Juz I, h. 236.

Amir Bad Syah, Taisir al-Tahrir Syarh 'Ala Kitab al-Tahrir fi Ushul al-Fiqh, Juz I, h. 87. 
Dari definisi yang dikemukakan di atas terlihat bahwa alSarakhsi lebih memerinci pengertian isyarah al-nash dari apa yang dikemukakan oleh Amir Bad Syah. Tetapi kedua definisi di atas mempunyai pengertian yang sama bahwa apa yang ditunjukkan oleh lafaz bukan itu yang dimaksud sebenarnya. Untuk mengetahui maksud sebenarnya diperlukan kecermatan analisis dan penalaran yang mendalam.

Contoh, surat al-Ahqaf ayat 15 yang menjelaskan bahwa lamanya masa mengandung dan menyusui bagi seorang ibu adalah 30 bulan. Berdasarkan ibarah al-nash ayat tersebut menunjukkan dan menjelaskan kemuliaan derajat ibu bagi anaknya, kemudian berdasarkan isyarahnya ayat tersebut mengandung konsekuensi pengertian bahwa sekurang-kurangnya masa kehamilan adalah enam bulan, karena pada Surat Lukman ayat 14 dinyatakan bahwa masa menyusui itu adalah sampai usia anak 2 tahun. Dengan demikian dari 30 bulan dikurangi 2 tahun (24 bulan) tinggallah 6 bulan untuk masa kehamilan. Kesimpulan bahwa minimal kandungan adalah 6 bulan bukan dimaksud oleh turunnya ayat, melainkan merupakan suatu keharusan dari ketegasan kedua ayat tersebut.

c. Dilalah al-nash

Definisi yang dikemukakan al-Sarakhsi adalah

$$
\text { ما تبت .معنى النظم لغة لا إستنباطا بالر أي } 8
$$

"Apa yang ditetapkan dengan makna menurut aturan bahasa dan bukan melalui cara istinbath dengan menggunakan nalar."

Sedikit lebih terperinci Amir Bad Syah mengemukakan

$$
\text { دل على حكم المنطوق لمسكوت لفهم مناطه مكجرد فهم اللغة } 9
$$

"Dilalah lafaz atas hukum yang dibicarakan untuk sesuatu yang tidak disebutkan karena dapat dipahami ada kaitannya berdasarkan pema- haman dari segi bahasa."

Abu Bakr Muhammad bin Ahmad bin Abi Sahl al-Sarakhsi, Ushul alSarakhsi, ditahqiq oleh Abu al-Wafa' al-Afghani, Juz I, h., h. 241.

Amir Bad Syah, Taisir al-Tahrir Syarh 'Ala Kitab al-Tahrir fi Ushul al-Fiqh, Juz I, h. 90. 
Dari definisi ini dapat disimpulkan bahwa dilalah al-nash adalah penunjukan oleh lafaz yang tersurat terhadap apa yang tersirat di balik lafaz itu. Hukum yang tersirat itu dapat diketahui cukup de- ngan pemahaman kebahasaan saja tanpa memerlukan penalaran atau ijtihad.

Contoh, surat al-Isra' ayat 23 yang melarang seorang anak untuk melontarkan perkataan yang menyakiti kedua orang tua. Berdasarkan ibarah al-nash, ayat ini menunjukkan keharaman mengatakan "ah" kepada ibu bapak, karena hal itu menyakiti hati mereka. Kemu- dian berdasarkan dilalah al-nash ayat ini menunjukkan keharaman memukul, mencaci maki, memenjarakan, mencegah mereka makan dan minum dan sebagainya, karena hal-hal tersebut jauh lebih menyakitkan hati kedua ibu bapak dari pada sekadar perkataan "ah".

\section{d. Iqtidha' al-nash}

Al-Sarakhsi mendefinisikan iqtidha' al-nash dengan

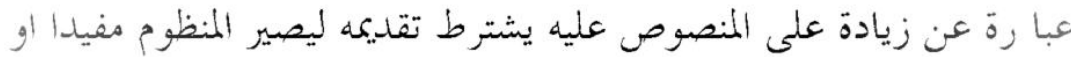

$$
\begin{aligned}
& \text { مو جبا للحكم وبدونه لا يمكن إعمال المنظو م" }
\end{aligned}
$$

"Ungkapan tambahan (sisipan) terhadap nash disyaratkan mendahului- nya supaya ada faedahnya terhadap hukum, tanpa sisipan itu tidak mungkin mengamalkan ayat."

Amir Bad Syah mendefinisikan dengan

$$
\text { الدلالة على المسكوت المتوقف عليه صدق المنطوق أو صحته إقتضاء11 }
$$

"Lafaz yang menunjukkan kepada sesuatu yang tidak disebutkan. Makna kebenaran dan kesahihannyya tergantung kepada makna yang tidak disebutkan itu."

Dari definisi di atas dapat diketahui bahwa iqtidha' al-nash adalah penunjukan suatu lafaz terhadap sesuatu yang tidak disebutkan se-

10 Abu Bakr Muhammad bin Ahmad bin Abi Sahl al-Sarakhsi, Ushul alSarakhsi, ditahqiq oleh Abu al-Wafa' al-Afghani, Juz I, h. 248.

11 Amir Bad Syah, Taisir al-Tahrir Syarh 'Ala Kitab al-Tahrir fi Ushul al-Figh, Juz I, h. 91. 
cara eksplisit dalam nash, namun keabsahan dan kebenaran lafaz itu mau tidak mau harus memperkirakan keberadaannya. Dengan kata lain pengertian kata yang disisipkan secara tersirat dalam pe- mahaman pada redaksi tertentu yang tidak dapat dipahami secara lurus kecuali dengan adanya penyisipan itu.

Contohnya adalah Hadis Nabi:

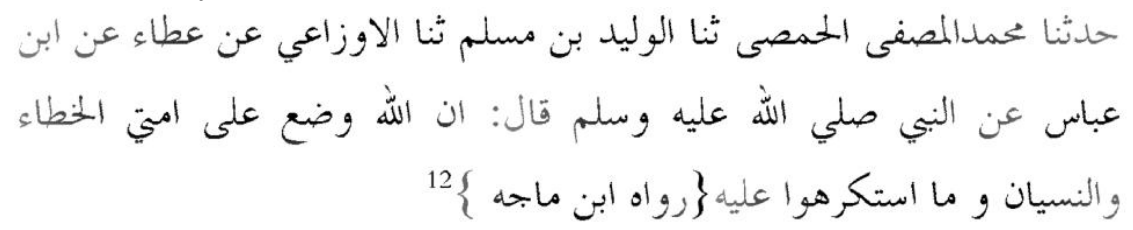

"Menyampaikan kepada kami Muhammad bin al-Mushaffa alHimshi, menyampaikan kepada kami Walid bin Muslim menyampaikan ke- pada kami al-Auza'I dari Atha' dari Ibn Abbas dari Nabi Saw, beliau te- lah bersabda Diangkatkan dari umatku kekeliruan, lupa, dan keterpak-saan."

Hadis ini secara harfiah menunjukkan bahwa kekeliruan, lupa, dan keterpaksaan telah diangkat dari umat Nabi Muhammad. Pengertian ini bertentangan dengan kenyataan karena perbuatanper- buatan tersebut ada dalam realitas kehidupan manusia. Oleh ka- rena itu dalam nash tersebut harus ada sesuatu yang diperkirakan keberadaannya, yaitu dosa atau hukuman, agar sesuai dengan ke- nyataan. Dengan demikian, yang diangkat bukan perbuatannya ka- rena perbuatan itu telah ada, melainkan yang diangkat adalah dosa yang ditimbulkan oleh perbuatan itu. Kata "dosa" tidak disebut- kan dalam hadis, teetapi harus diperkirakan adanya, supaya dapat dipahami secara benar.

\section{Ulama al-Mutakallimin}

Al-mutakallimin membagi petunjuk lafaz terhadap hukum kepada dua: manthuq dan mafhum.

12 Abu Abd Allah Muhammad bin Yazid al-Qazwini, Sunan Ibn Majah, ditahqiq dan dita'liq oleh Muhammad Fu'ad Abd al-Baqi, (Bairut: Dar al-Kutub alIlmiyah, t.th). Jilid 1, h. 659. 


\section{a. Manthuq}

Manthuq adalah isim maf'ul yang secara bahasa berasal dari kata nathaqa-yanthiqu-nuthqan yang berarti pembicaraan. ${ }^{13}$ Sedangkan pengertian secara istilah adalah sebagaimana yang dikemukakan oleh al-Amidi ${ }^{14}$

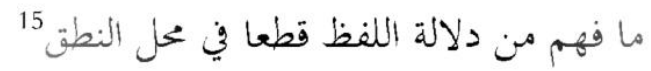

"Makna yang dipahami dari petunjuk lafaz secara qath'i terhadap pembicaraan."

Selanjutnya definisi yang dikemukakan oleh al-Juwaini: ${ }^{16}$

$$
\text { متلقى من المنطرق به المصرح بذكر } 17^{\circ}
$$

"Pengertian yang diperoleh dari apa yang tersurat."

\section{Menurut Ibn Subki sebagaimana yang dikutip oleh Musthafa} Said al-Khin

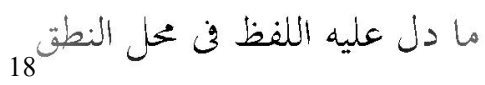

"Petunjuk suatu lafaz berdasarkan apa yang diucapkan."

13 Al-'Alamah ibn Manzhur, Lisan al-'Arabi, (Bairut: Dar aal-Fikr, t.th), Jilid 12, h. 231.

14 Nama lengkapnya adalah Saif al-Din Ali bin Abi Ali bin Muhammad bin Salim al-Taghlibi al-Amidi, Lahir pada tahun $551 \mathrm{H}$ di Amid (Turki) dan wafat tahun 631 di Damaskus dalam usia 80 tahun. Pada awalnya ia adalah seorang tokoh mazhab Hanbali yang kemudian berpindah ke mazhab Syafi'i. Syams al-Din Muhammad bin Ahmad bin Usman al-Dzahabi, Sir A'lam alNubala,,(Bairut: Muassasah al-Risalah, 1986), Jilid 22, h. 364.

15 Saif al-Din Abi Al-Hasan Ali bin Abi Ali bin Muhammad al-Amidi, AlIhkam fi Ushul al-Ahkam, ( Bairut: Dar al-Fikr, 1996), Jilid 3, h. 46.

16 Nama lengkapnya adalah Abu al-Ma'ali 'Abd al-Malik Ibn Abi Muhammad Abd Allah bin Yusuf bin Abd Allah bin Yusuf ibn Muhammad bin Hayyuwiyah alJuwaini. Ia dikenal juga dengan nama Imam Haramain, lahir pada tahun 419

$\mathrm{H}$ di Naisabur dan wafat tanggal 25 Rabi'ul Awal tahun 478 H. Syams al-Din Muhammad bin Ahmad bin Usman al-Dzahabi, Sir A 'lam al-Nubala', Jilid 18, h. 468 dan 476 .

17 Al-Juwaini, al-Burhan fi Ushul al-Fiqh, (Bairut: Dar al-Kutub al-Ilmiyah, 1997), h. 165.

18 Musthafa Said al-Khin, Atsar al-Ikhtilaf fi al-Qawa'id al-Ushuliyah fi Ikhtilaf 
Sa'id Ramadhan al-Buthi mendefinisikan manthuq dengan

$$
\text { كل ما دل عليه اللفظ ضمن داءرة النطق } 19
$$

"Setiap petunjuk lafaz yang terkandung di sekitar pembicaraan."

Dari semua definisi di atas ini dapat disimpulkan bahwa manthuq ialah memahami dari apa yang langsung tersurat dalam lafaz. Misal, Surat al-Nisa'ayat 23 yang melarang seorang suami mengawini anak tiri yang berada dalam asuhannya. Ayat ini menurut manthuqnya menunjukkan keharaman menikahi anak tiri yang berada di bawah asuhan suami dari istri yang telah digauli. Apa yang ditunjuk di sini memang jelas terbaca dalam apa yang tersurat dalam ayat terse- but. Penunjukannya begitu jelas sehingga tidak memerlukan penje- lasan di balik yang tersurat itu. ${ }^{20}$

Kemudian manthuq ini dibagi kepada dua: sharih dan ghairu sharih. Manthuq Sharih adalah petunjuk lafaz kepada seluruh pengertian yang dikehendaki atau sebagiannya saja. ${ }^{21}$ Manthuq Sharih dalam istilah ulama Syafi'iyah ini adalah apa yang diistilahkan dengan ibarah al-nash dalam istilah ulama Hanafiyah.

Manthuq ghairu sharih adalah petunjuk lafaz atas suatu ketentuan hukum yang diperoleh dengan melihat keterkaitan yang tidak bisa dipisahkan dari manthuq. ${ }^{22}$ Amir Syarifuddin menyatakan bahwa Manthuq ghairu sharih terbagi kepada dua macam: 1). Penunjukan- nya itu dimaksud oleh pembicara, 2). Penunjukannya itu tidak dimaksud oleh pembicara.

1. Dilalah manthuq ghairu sharih yang penunjukannya dimaksud oleh pembicara ada dua macam yaitu dilalah iqtidha' dan dilalah ima'. Dilalah iqtidha' ini di kalangan Hanafiyah juga disebut de-

al-Fuqaha', (Bairut: Muassasah al-Risalah, 1972), h. 138.

19 Sa'id Ramadhan al-Buthi, Mabahits al-Kitab wa al-Sunnah min Ilm al-Ushul, (Damsyiq: al-Mathba'ah al-Ta'awuniyah, 1975), h. 40.

20 Amir Syarifuddin, Ushul Fiqh, Jilid 2, h. 145.

21 Musthafa Said al-Khin, Atsar al-Ikhtilaf fi al-Qawa'id al-Ushuliyah fi Ikhtilaf al-Fuqaha', h. 139.

22 Musthafa Said al-Khin, Atsar al-Ikhtilaffi al-Qawa'id al-Ushuliyah fi Ikhtilaf al-Fuqaha', h. 139. 
ngan dilalah iqtidha' atau iqtidha' al-nash.

2. Dilalah manthuq ghairu sharih yang penunjukannya tidak di- maksud oleh pembicara hanya terbatas pada satu bentuk yang disebut dengan dilalah isyarah, yang di kalangan Hanafi juga disebut dilalah isyarah atau isyarah al-nash. ${ }^{23}$

b. Mafhum

Al-Amidi menyatakan:

$$
\text { ما فهم من اللفظ في غيره محل النطق }
$$

"Makna yang dipahami dari lafaz bukan menurut yang dibicarakan."

Al-Juwaini mendefinisikan mafhum dengan

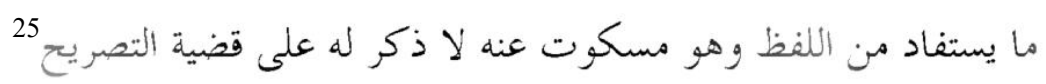

"Pengertian yang diperoleh dari arti yang tidak disebutkan secara je-las."

Berdasarkan definisi ini dapat diketahui bahwa mafhum adalah se- tiap makna yang dipahami dari suatu lafaz yang makna tersebut berada di luar ruang lingkup yang tersurat.

Mafhum terbagi dua yaitu mafhum muwafaqah dan mafhum mukha- lafah. Mafhum muwafaqah adalah

$$
\text { ما يفهم من الكالام بطريق المطابقة }
$$

"Makna yang dipahami dari kalimat dengan jalan muthabaqah (kesesuaian antara yang disebutkan dengan yang tidak disebutkan."

Sedangkan mafhum mukhalafah adalah

$$
\text { ان يثبت الحكم فن المسكوت على خحلاف ما ثبت في المنطوق } 27
$$

23 Amir Syarifuddin, Ushul Fiqh, Jilid 2, h. 145.

24 Saif al-Din Abi Al-Hasan Ali bin Abi Ali bin Muhammad al-Amidi, AlIhkam fi Ushul al-Ahkam, Jilid 3, h. 46.

25 Al-Juwaini, Al-Burhan fi Ushul al-Fiqh, h. 165.

26 Ali bin Muhammad bin ali al-Jurjani, Kitab al-Ta'rifat. Ditahqiq oleh Ibrahim al-Abyari, (t.t: Dar al-Kitab al-'Arabi, t.th), h. 289. 
"Menetapkan hukum yang tidak disebutkan berbeda dengan hukum yang disebutkan."

\section{Mafhum Muwafaqah}

\section{Pembagian Mafhum Muwafaqah}

Sebagaimana yang telah dijelaskan di atas bahwa mafhum muwafaqah adalah

Makna lafaz yang tidak disebutkan dalam manthuqlangsung bisa ditangkap dari lafaz itu — sama hukumnya dengan makna yang dipahami dari lafaz itu sendiri.

Mafhum muwafaqah terbagi kepada dua macam yaitu fahwa alkhitab (mafhum aulawi) dan lahna al-khitab (mafhum musawi). Jika hukum yang tidak disebutkan lebih kuat dibandingkan dengan hu- kum yang disebutkan dinamakan dengan fahwa al-khitab, seperti ha- ramnya memaki dan memukul orang tua berdasarkan petunjuk ayat tentang haramnya mengucapkan "ah" kepada orang tua sebagaimana yang terdapat dalam surat al-Isra' ayat 23. Hukum yang tersurat dalam ayat ini adalah larangan berkata kasar atau "ah" dan menghardik orang tua. Maka, hukum memaki dan memukul orang tua adalah haram sebagaimana haramnya berkata "ah" karena sifat menyakiti dalam memaki dan memukul lebih kuat dari sifat menyakiti dalam ucapan "ah".

Sedangkan lahna al-Khitab adalah hukum yang tidak disebutkan sama kekuatannya dengan hukum yang disebutkan, seperti memakan harta anak yatim. Sebagaimana yang terdapat dalam surat al-Nisa' ayat 10 yang menjelaskan larangan memakan harta anak yatim secara aniaya. Manthuq ayat ini menunjukkan haramnya memakan harta anak yatim secara aniaya. hukum memakan harta anak yatim sama saja dengan hukum melenyapkan, membuang atau membakarnya karena pada hakikatnya makna-makna ini mengacu pada satu hal, yaitu menghabiskan harta anak yatim secara zalim. ${ }^{28}$

27 Ali bin Muhammad bin Ali al-Jurjani, Kitab al-Ta'rifat. Ditahqiq oleh Ibrahim al-Abyari, h. 289.

28 Saif al-Din Abi Al-Hasan Ali bin Abi Ali bin Muhammad al-Amidi, Al-Ihkam fi

Ushul al-Ahkam, Jilid 3, h. 47, Lihat juga Amir Syarifuddin, Ushul Fiqh, Jilid 


\section{Kehujjahan Mafhum Muwafaqah}

Para ulama sependapat tentang sahnya berhujjah dengan mafhum muwafaqah. Hanya kalangan ulama Zhahiri yang menolak menetapkan hukum dengan mafhum, sebagaimana juga menolak menggunakan qiyas, karena menurut mereka mafhum muwafaqah dalam hal ini sama dengan qiyas. $^{29}$ Meskipun ulama ushul fikih sepakat dengan kehujjahan mafhum muwafaqah, tetapi mereka berbeda pendapat mengenai cara menetapkan hukum melalui mafhum muwafaqah.

a. Mazhab Mutakallimin, al-Asy'ariyah dan Mu'tazilah, berpendapat bahwa penemuan hukum itu dilakukan melalui dilalah lafaz.

b. Al-Syafi'i, Al-Juwaini dan Al-Razi berpendapat bahwa penemuan hukum dilakukan melalui qiyas yaitu qiyas jali. ${ }^{30}$

Pendapat pertama menyatakan bahwa pemahaman terhadap maknamakna dilakukan melalui dilalah lafaz, bukan melalui qiyas. Oleh karena itu adanya larangan mengucapkan "ah" pada orang tua ti- dak berarti haram memukul dan memaki orang tua. Memukul orang tua haram bukan berdasarkan ayat tersebut, melainkan berdasarkan ayat lain yang menyuruh berbuat baik kepada orang tua. Begitu pula halnya dengan larangan membakar harta anak yatim

Sedangkan bagi pendapat yang kedua yang berpendapat bahwa penunjukan lafaz terhadap mafhum muwafaqah dilakukan melalui qiyas, maka larangan memukul dan memaki orang tua diqiyaskan kepada larangan mengucapkan kata "ah" karena antara keduanya mempunyai ilat yang sama yaitu sama-sama menyakiti. Begitu juga dengan larangan membakar, merusak harta anak yatim merupakan pengqiyasan terhadap larangan memakan yang terdapat dalam ayat karena adanya kesamaan illat, yaitu menghabisi harta anak yatim.

2, h., h. 147-148.

29 Golongan al-Zhahiriyah menolak penggunaan qiyas secara mutlak. Dalam kitab al-Ihkam fi Ushul al-Ahkam, Ibn Hazm menjelaskan secara panjang lebar argumentasi penolakan terhadap qiyas. Lihat Abu Muhammad Ali bin Ahmad bin Said bin Hazm al-Zhahiri, Al-Ihkam fi Ushul al-Ahkam, (Bairut: Dar al-Kutub al-Ilmiyyah), Jilid 2, h. 515-550.

30 Musthafa Said al-Khin, Atsar al-Ikhtilaf fi al-Qawa'id al-Ushuliyah fi Ikhtilaf al-Fuqaha', h. 152. Sa'id Ramadhan al-Buthi, Mabahits al-Kitab wa alSunnah min Ilm al-Ushul, h. 44. 


\section{Atsar Ikhtilaf}

Untuk melihat pengaruh perbedaan pendapat ulama ushul dalam mafhum muwafaqah terhadap fikih, maka di sini akan dikemukakan sebuah persoalan tentang korupsi. Apakah korupsi termasuk ke dalam pengertian sirqah atau tidak, sehingga kepada pelaku korupsi akan diberlakukan ketentuan yang terdapat dalam Surat al-Maidah ayat 38 yang menjelaskan bahwa orang yang mencuri baik laki-laki maupun perempuan akan dikenakan had potong tangan. Oleh karena itu untuk menetapkan hukuman yang akan diberikan kepada pelaku korupsi, akan dilihat terlebih dahulu apakah korupsi itu termasuk dalam pengertian sirqah atau tidak.

Sirqah secara bahasa adalah mengambil harta orang lain secara sembunyi-sembunyi. ${ }^{31}$ Sedangkan pengertian secara istilah adalah seorang mukallaf mengambil harta orang lain secara sembunyi-sembunyi dalam jumlah tertentu pada tempat penyimpanannya atau tempat pemeliharaannya. ${ }^{32}$

Dari definisi ini dapat diketahui bahwa sirqah yang dikenakan had potong tangan ialah mengambil secara sembunyi-sembunyi ba- rang berharga milik orang lain dalam ukuran tertentu yang disimpan oleh pemiliknya pada tempat yang wajar atau pada tempat peyim- panannya.

Berdasarkan dilalah lafaz korupsi tidak termasuk ke dalam penger- tian sirqah, korupsi berbeda dengan sirqah. Sirqah mengambil harta orang lain secara sembunyi-sembunyi, sedangkan korupsi mengambil harta orang lain yang sudah diamanatkan kepadanya. Itu sebabnya siapa pun yang mengambil sesuatu yang bukan miliknya namun diamanatkan kepadanya tidak termasuk dalam pengertian mencuri oleh ayat ini. Sehingga had sirqah tidak dapat diberikan kepada pelaku korupsi.

Sementara itu kalau berdasarkan kepada mafhum muwafaqah atau

31 Al-Jurjani, Ali bin Muhammad bin Ali al-Jurjani, Kitab al-Ta'rifat. Ditahqiq oleh Ibrahim al-Abyari, h. 146. Muhammad Rawwas Qal'ah Ji dan Hamid Shadiq Qunaibi, Mu'jam Lughah al-Fuqaha', (Bairut: Dar al-Nafa-is, 1985), h. 234.

32 Ali bin Muhammad bin Ali al-Jurjani, Kitab al-Ta'rifat. Ditahqiq oleh Ibrahim al-Abyari, Al-Jurjani, h. 146. 
qiyas maka korupsi termasuk dalam pengertian sirqah karena adanya kesamaan illat antara keduanya, yaitu sama-sama mengambil harta orang lain dengan jalan yang tidak dibenarkan oleh syara', sehingga had sirqah dapat diberlakukan kepada pelaku korupsi.

\section{Kesimpulan}

Ulama ushul berbeda pendapat tentang petunjuk lafaz terhadap hu- kum. Ulama hanafiyah membagi kepada empat Ibarah, isyarah dila- lah dan iqtidha' al-nash, sementara ulama Mutakallimin membagi kepada dua yaitu manthuq dan mafhum. Manthuq terbagi dua yaitu manthuq sharih dan ghairu sharih. Mafhum terbagi dua muwafaqah dan mukhalafah. Mafhum muwafaqah adalah makna lafaz yang tidak disebutkan sama hukumnya dengan makna yang dipahami dari lafaz itu sendiri.

Walaupun ulama sepakat tentang kehujahan mafhum muwafaqah, tetapi mereka berbeda tentang cara menetapkan hukum melalui mafhum muwafaqah. Ada yang berpendapat melalui qiyas dan ada yang berpendapat melalui dilalah lafaz. Perbedaan ini berpengaruh terhadap penetapan hukum atas suatu kasus. Bagi ulama yang berpendapat bahwa hukum dapat ditetapkan melalui qiyas, maka berdasarkan ayat yang dimaksud dapat ditetapkan hukum. Tetapi bagi ulama yang menetapkan hukum melalui dilalah lafaz maka ayat yang dimaksud tidak dapat digunakan untuk menetapkan hukum suatu kasus. Itu sebabnya untuk menetapkan hukum terhadap kasus yang dimaksud perlu dicari dalil lain.

DILALAH LAFAZ MENURUT HANAFIYAH DAN MUTAKALLIMIN

\begin{tabular}{|l|l|l|l|l|}
\hline & Isyrah al-Nash & Dilalah Iqtidha' & Dilalah al-nash & Ibarah al-Nash \\
\hline Hanafiyah & Isyrah al-Nash & Dilalah Iqtidha' & $\begin{array}{l}\text { Dilalah al- } \\
\text { nash }\end{array}$ & Ibarah al-Nash \\
\hline $\begin{array}{l}\text { Mutakal- } \\
\text { limin }\end{array}$ & Isyrah al-Nash & Dilalah Iqtidha' & $\begin{array}{l}\text { Mafhum Mu- } \\
\text { wafaqah }\end{array}$ & $\begin{array}{l}\text { Manthuq } \\
\text { Sharih dan } \\
\text { Dilalah al-Ima' }\end{array}$ \\
\hline
\end{tabular}




\section{DAFTAR PUSTAKA}

Al-Amidi, Saif al-Din Abi Al-Hasan Ali bin Abi Ali bin Muhammad, Al-Ihkam fi Ushul al-Ahkam, Bairut: Dar al-Fikr, 1996, Jilid I.

Al-Buthi, Sa'id Ramadhan, Mabahits al-Kitab wa al-Sunnah min Ilm al-Ushul, Damsyiq: al-Mathba'ah al-Ta'awuniyah, 1975.

Al-Dzahabi, Syams al-Din Muhammad bin Ahmad bin Usman, Sir A 'lam al-Nubala', Bairut: Muassasah al-Risalah, 1986, Jilid 18, 22.

al-Hanafi, Mushthafa bin Abd Allah al-Qushthanthani al-Rumi, Kasyf al-Zhunun 'an Asami al-Kutub wa al-Funun, Bairut: Dar al-Fikr, 1994, jilid 1.

Al-Husaini, Amir Bad Syah, Taisir al-Tahrir Syarh 'Ala Kitab altahrir, Bairut: Dar al-Kutub al-Ilmiyyah, t.th.

Al-Jurjani, Ali bin Muhammad bin Ali, Kitab al-Ta'rifat. Ditahqiq oleh Ibrahim al-Abyari, t.t: Dar al-Kitab al-'Arabi, t.th.

Al-Juwaini, al-Burhan fi Ushul al-Fiqh, Bairut: Dar al-Kutub alIlmiyah, 1997.

Al-Khin, Musthafa Said, Atsar al-Ikhtilaf fi al-Qawa'id al-Ushuliyah fi Ikhtilaf al-Fuqaha', Bairut: Muassasah al-Risalah, 1972.

al-Qazwini, Abu Abd Allah Muhammad bin Yazid, Sunan Ibn Majah, ditahqiq dan dita'liq oleh Muhammad Fu'ad Abd al-Baqi, Bairut: Dar al-Kutub al-Ilmiyah, t.th, Jilid 1.

Al-Sarakhsi, Abu Bakr bin Muhammad bin Ahmad bin Abi Sahl, Ushul al-Sarakhsi, di tahqiq oleh Abu al-Wafa' al-Afghani, Bairut: Dar al-Kutub al-Ilmiyyah, 1993, Juz I.

al-Zhahiri, Abu Muhammad Ali bin Ahmad bin Said bin Hazm, AlIhkam fi Ushul al-Ahkam, Bairut: Dar al-Kutub al-Ilmiyyah, Jilid 2.

Ibn Manzhur, Al-'Alamah, Lisan al-'Arabi, Bairut: Dar aal-Fikr, t.th, Jilid 12.

Qal'ah Ji, Muhammad Rawwas dan Hamid Shadiq Qunaibi, Mu'jam Lughah al-Fuqaha', Bairut: Dar al-Nafa-is, 1985.

Syarifuddin, Amir, Ushul Fiqh, Jakarta: Logos, 1999, Jilid 2. 